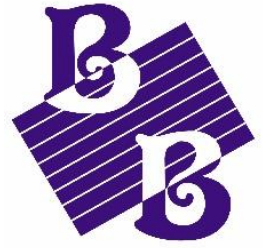

BioBacta

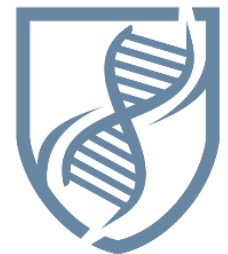

Journal of Bioscience and Applied Research www.jbaar.org

\title{
Using starchy waste as a promising raw material for bioethanol production with consequence purification using chitosan/sodium alginate polymeric membrane
}

\author{
Tarek H. Taha ${ }^{\text {* }}$, M. A. Abu-Saied ${ }^{2 *}$, Elsayed M. Elnaggar ${ }^{3}$, Ranya A. Amer ${ }^{4}$, \\ Ahmed E. Mansy ${ }^{4}$, Gamal M. Elkady ${ }^{3}$ \\ ${ }^{1}$ Environmental Biotechnology Department, Genetic Engineering and Biotechnology Research Institute (GEBRI), City \\ of Scientific Research and Technological Applications (SRTA-City), New Borg El-Arab, 21934, Alexandria, Egypt. \\ ${ }^{2}$ Polymer Materials Research Department, Advanced Technology and New Materials Research Institute, City of \\ Scientific Research and Technological Applications (SRTA-City), New Borg El-Arab, 21934, Alexandria, Egypt. \\ ${ }^{3}$ Chemistry Department, Faculty of Science, Al-Azhar University, Cairo, Egypt, 11884. \\ ${ }^{4}$ Environment and Natural Materials Research Institute (ENMRI), City of Scientific Research and Technological \\ Applications (SRTA-City), New Borg El-Arab, 21934, Alexandria, Egypt.

\section{Corresponding authors} \\ E-mail addresses: ttaha@srtacity.sci.eg (Tarek H. Taha) mouhamedabdelrehem@yahoo.com (M. A. Abu-Saied) \\ DOI: $10.21608 /$ JBAAR. 2019.138664
}

\section{Abstract}

The current study is concerned with using environmental wastes as raw materials for bio-ethanol production. The alpha-amylase enzyme has been used to convert the starch molecules of kitchen waste into simple units of glucose which are subsequently fermented into bioethanol. The obtained results showed that $40 \%$ substrate and $100 \mu \mathrm{l}$ of $\alpha$-amylase were the optimum concentration to produce the highest glucose units at 417.9 and 482.5 milligram/deciliter $(\mathrm{mg} / \mathrm{dl})$, respectively. The highest bioethanol production of $423.5 \mathrm{mg} / \mathrm{dl}$ was obtained after anaerobic fermentation of free yeast cells at $30^{\circ} \mathrm{C}$ without shaking. Both bio-ethanol and $25 \%$ ethanol were separated by using an amicon cell ultra-filtration system integrated with chitosan or sodium alginate membranes under nitrogen pressure. Each membrane was characterized by Scanning Electron Microscope (SEM) and Ion Exchange Capacity (IEC); while, the hydrophilicity/hydrophobicity was investigated using contact angle. The whole system succeeded to elevate the ethanol concentration in a range of 47-50\%, which could be increased with more polymeric modifications.

Keywords: Environmental waste, Chitosan, and sodium alginate membranes, Production of bio-ethanol, Bioethanol/water polymeric separation. 


\section{Introduction}

Biofuels produced from renewable biomass have recently received considerable attention. Ethanol can be used as an additive to gasoline fuel or as a transportation fuel. The incorporation of bioethanol into fuels helps to alleviate global warming and environmental pollution. The upcoming depletion and the increasing value of petroleum products have renewed the interest in the production of bioethanol and its use as an alternative fuel or as chemical feedstock (Goshadrou, Karimi, \& Taherzadeh, 2013; Mahalakshmi, Angayarkanni, Rajendran, \& Rajesh, 2011). Therefore, it was necessary to find dual alternative solutions that focus upon alternative energies with simultaneous reduction of the environmental pollution sources. Some countries depend on crops such as corn and wheat as a source for the production of biofuel (Onuki et al., 2008; Zaldivar, Nielsen, \& Olsson, 2001). Such materials cannot be reliable, in the long term as energy sources because they are considered the main sources of human-edible foods. Other countries depend on agricultural wastes as sources of biofuel production. However, the lack of them will harm the animals as these wastes are considered the main animal feed (Braide, Kanu, Oranusi, \& Adeleye, 2016; Sarkar, Ghosh, Bannerjee, \& Aikat, 2012). Recent studies are currently focusing on using food-wastes instead (Kim, Lee, \& Pak, 2011; Matsakas \& Christakopoulos, 2015). Food waste contains a high percentage of carbohydrate that can be easily hydrolyzed using enzymatic hydrolysis (Alvira, Tomás-Pejó, Ballesteros, \& Negro, 2010), the enzyme work on starchy material to yield free glucose units which can be fermented by microbes to produce bio-ethanol (Noufal, Li, \& Maalla, 2017; Tanimura et al., 2015). The produced bio-ethanol can be used as a source of energy but after the purification process. The most traditional process used for the recovery of ethanol is distillation, which is considered a challenge because of the high costs and energy expenditure required (Vane, 2008). Toward this end, membrane separation processes that are applied through the pervaporation technique have been used. The great interest in these processes is mainly because of features such as cost-effectiveness, high energy efficiency and environmental friendliness. Recent technologies that based on membrane separation are normally fulfill the required criteria of energy efficiency and sustainability (Bello et al., 2014; Korelskiy et al., 2013). This study aimed to bioconversion of environmental wastes, which cause serious environmental problems, into beneficial products. The study was concerned by increasing the liberation rates of glucose units using enzymatic treatments followed by anaerobic fermentation of liberated glucose units into bioethanol. The study was extended to prepare polymeric membranes that can enhance the bioethanol/water separation process.

\section{MATERIALS AND METHOD \\ 2.1. MATERIALS}

The kitchen wastes were collected from different restaurants in different locations in Borg El-Arab, Alexandria, Egypt. Sodium hydroxide $(\mathrm{NaOH})$ pellets, Chitosan (CS) with a degree of acetylation of 84\% and average M.wt 500000 were obtained from Acros organics, Belgium. Sulfuric acid $\left(\mathrm{H}_{2} \mathrm{SO}_{4}\right)$ and HPLC grade absolute Ethanol were purchased from Fisher Scientific UK. Both of the yeast strain (Saccharomyces cerevisiae) \& amylase enzyme were kindly provided by the industrial bioprocess department, GEBRI institute, City of scientific research and technological applications, and potassium dichromate $\left(\mathrm{K}_{2} \mathrm{Cr}_{2} \mathrm{O}_{7}\right)$ were purchased from Sigma-Aldrich, USA. The glucose kit was purchased from Biosystems, Spain. Sodium alginate (SA), Technical, SLR was purchased from Fisher chemical UK.

\subsection{METHODS}

\subsubsection{Selection of the type of waste}

As kitchen wastes include a vast number of organic components, the starchy category (especially rice) was chosen as the raw material for the production of bioethanol.

\subsubsection{Optimization Parameters}

\subsubsection{Substrate concentration}


A wide range of rice concentrations as 10, 20, 30, 40,

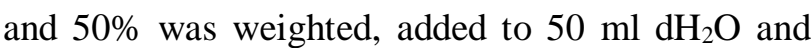
sterilized at $15 \mathrm{psi}$ and $120^{\circ} \mathrm{C}$ for $20 \mathrm{~min}$. After sterilization, the glucose concentration was firstly measured to check the ability of autoclaving to degrade the bonds of the starch backbone and liberate the glucose units. The flasks were cooled and $50 \mu \mathrm{l}$ of the crude $\alpha$-amylase enzyme were added, mixed, and kept at $30^{\circ} \mathrm{C}$ for three hours. The liberated glucose units were then measured and the optimum substrate concentration was determined.

\subsubsection{Enzyme concentration}

After the determination of the optimum concentration of the substrate, it was selected and submitted to different concentrations of the amylase enzyme. For more clarification, five conical flasks of the optimum weight of rice were prepared and sterilized at $15 \mathrm{psi}$ and $120^{\circ} \mathrm{C}$ for $20 \mathrm{~min}$. To each flask, a single inoculum of $20,40,60,80$, and $100 \mu$ l of the crude enzyme was added individually (where each microliter of the crude enzyme equals a concentration of $2.5 \mu \mathrm{g} / \mathrm{ml}$ ). After three hours of incubation at $30^{\circ} \mathrm{C}$, the final released glucose concentrations were measured and calculated in $\mathrm{mg} / \mathrm{dl}$.

\subsubsection{Determination of glucose concentration}

The concentration of free glucose units was measured in $\mathrm{mg} / \mathrm{dl}$ using (Biosystem, Spain) glucose kit according to the manual instructions.

\subsubsection{Glucose separation and yeast inoculation}

The optimum conditions for the liberation of the highest glucose concentration were applied, and soluble glucose units were separated from the rice debris through centrifugation at $6000 \mathrm{rpm}$ for $10 \mathrm{~min}$. The obtained supernatant was transferred to a sterile container and $1 \mathrm{ml}$ of free and immobilized overnight cultures of Saccharomyces cerevisiae that grew in YPG broth were added under septic conditions.

\subsubsection{Immobilization of yeast cells in Ca-alginate} Immobilization of yeast cells in Ca-alginate beads was carried out under septic conditions according to (Taha, Alamri, Mahdy, \& Hafez, 2013). Two milliliters of overnight culture were suspended in 5 $\mathrm{ml}$ of $3 \%(\mathrm{w} / \mathrm{v})$ sodium alginate solution. The obtained mixture was dropped through a syringe nozzle into $100 \mathrm{ml}$ of $3.5 \%(\mathrm{w} / \mathrm{v}) \mathrm{CaCl}_{2}$ solution. Alginate drops were cross-linked upon their contact with $\mathrm{Ca}^{+2}$ ions, forming spherical beads and thus entrapping the yeast cells. The beads were allowed to harden for $30 \mathrm{~min}$ and were then washed with a sterile normal saline solution $(0.9 \% \mathrm{NaCl})$ to remove any excess $\mathrm{Ca}^{+2}$ ions and cells.

\subsubsection{Fermentation}

The free and immobilized yeast cells were inoculated into glucose-containing flasks and were then submitted to anaerobic conditions by surface addition of $50 \mu \mathrm{l}$ mineral oil. The flasks were then incubated statically at $25^{\circ} \mathrm{C}$ for three days, and the concentration of the formed bioethanol was measured spectrophotometrically.

\subsubsection{Spectrophotometric measurement of bioethanol concentration}

Potassium dichromate analytical method was used for estimation of produced bio-ethanol according to (Balasubramanian, Ambikapathy, \& Panneerselvam, 2011; Hashem, Asseri, Alamri, \& Alrumman, 2018; Srivastava, Agrawal, \& Rahiman, 2014) with some modifications. After centrifugation of each culture at $1000 \mathrm{rpm}$ for $10 \mathrm{~min}, 1 \mathrm{ml}$ of each ferment was diluted by $4 \mathrm{ml}$ of distilled water followed by the addition of $1 \mathrm{ml}$ of $2 \% \mathrm{~K}_{2} \mathrm{Cr}_{2} \mathrm{O}_{7}$. The tubes were kept on an ice bath while $1 \mathrm{ml}$ of concentrated $\mathrm{H}_{2} \mathrm{SO}_{4}$ was drop wisely added. After $10 \mathrm{~min}$ incubation at room temperature, the absorbance of each sample was measured by spectrophotometry at $660 \mathrm{~nm}$ against a blank sample contained $1 \mathrm{ml} \mathrm{dH}_{2} \mathrm{O}$ instead of the ferment. The obtained readings were dropped to the ethanol standard curve and the ethanol concentration was calculated.

\subsubsection{Polymeric separation of ethanol-water mixture}

The Polymeric separation of the produced bioethanol was achieved through two steps: the first step included the preparation of polymeric (Chitosan and Sodium alginate) membranes. The second step depended on using an amicon stirred ultrafiltration cell (USA) integrated with the polymeric membranes. Different nitrogen pressures from 20 to 60 psi were 
applied and the volume and concentration of each permeate solution were measured each one hour.

\subsubsection{Membrane preparation}

Chitosan membrane (CS) was prepared by adding $2 \%$ $(\mathrm{W} / \mathrm{V})$ solution of $\mathrm{CS}$ in $2 \%(\mathrm{~V} / \mathrm{V})$ aqueous acetic acid, stirred for half an hour then filtered to remove un-dissolved and suspended matter. A bubble-free solution was cast onto a clean glass plate and evaporated to dryness at room temperature for $24 \mathrm{~h}$, followed by overnight vacuum drying in an oven at $40^{\circ} \mathrm{C}$ to remove the presence of a residual solvent, if any.

Sodium alginate membrane (SA) was prepared by solution casting and solvent evaporation method. A quantity of $3 \mathrm{~g}$ of SA was dissolved in $100 \mathrm{ml}$ distilled water then stirred to be completely soluble. The solution was cast on a clean acrylic plate petri dish to the desired thickness and dried in atmospheric condition at room temperature, followed by vacuum drying for $5 \mathrm{~h}$ at $50^{\circ} \mathrm{C}$ to remove the last traces of solvent.

\subsubsection{Membrane characterization}

The morphology of CS and SA membranes were characterized by scanning electron microscope (JEOL, JSM-6360LA, Japan), water contact angle measurements were obtained using contact angle meter VCA 2500 XE equipped with CCD camera and analysis software (AST Products, Billerica, MA).

\subsection{Ion Exchange Capacity (IEC)}

Ion exchange capacity was measured by using acidbase titration according to (Abu-Saied, Fontananova, Drioli, \& Eldin, 2013; Abu-Saied et al., 2017) with some modifications. Weighted samples from each membrane before and after separation were placed in $20 \mathrm{ml}$ of $2 \mathrm{M} \mathrm{NaCl}$ solution at room temperature for 12h. The solution was then titrated with a known concentration of $\mathrm{NaOH}$ solution, using phenolphthalein as an indicator. The IEC can be calculated from the following equation:
$\operatorname{IEC}(\mathrm{meq} / \mathrm{g})=\left(\frac{\mathrm{C}(\mathrm{NaOH}) \times \mathrm{V}(\mathrm{NaOH})}{\text { Dry weight of sample }}\right)$

Where $\mathrm{C}$ is the molar concentration of $\mathrm{NaOH}$ solution, and $\mathrm{V}$ is the volume $(\mathrm{ml})$ of consumed $\mathrm{NaOH}$.

\section{Results and Discussion}

\subsection{Optimization Parameters}

\subsubsection{The optimum substrate concentration}

The obtained results revealed that the autoclaving process was unable to liberate the glucose units from the starch backbone, indicating that other methods are needed. The data obtained after the addition of the $\alpha$ amylase enzyme were significant, indicating that enzymatic biodegradation is the most preferable method. As shown in figure 1 , the ability of an $\alpha$ amylase enzyme to liberate glucose units from starch was highly dependent on the substrate concentration. At lower concentrations, the activity of the enzyme was quite elevated, which allow the enzyme molecules to freely hang out between the substrate molecules and easily find the suitable degradation position (Saha, Baishnab, Alam, Khan, \& Islam, 2014). However, at higher concentrations, the attached and closely linked starch molecules make the pathway of the enzyme quite crowded and hardened the mission accomplishment. These concepts are almost reflected through the results of the concentrations of released glucose units from 10 to $30 \%$ of rice. The obtained results showed that these concentrations were able to produce $122-299.2 \mathrm{mg} / \mathrm{dl}$ glucose at $10-30 \%$ of rice. However, the highest glucose concentration of $417.9 \mathrm{mg} / \mathrm{dl}$ was obtained at $40 \%$ of rice, which subsequently decreased to 362.5 $\mathrm{mg} / \mathrm{dl}$ at $50 \%$. These results confirm the principle of the lower concentration-dependent concept. 


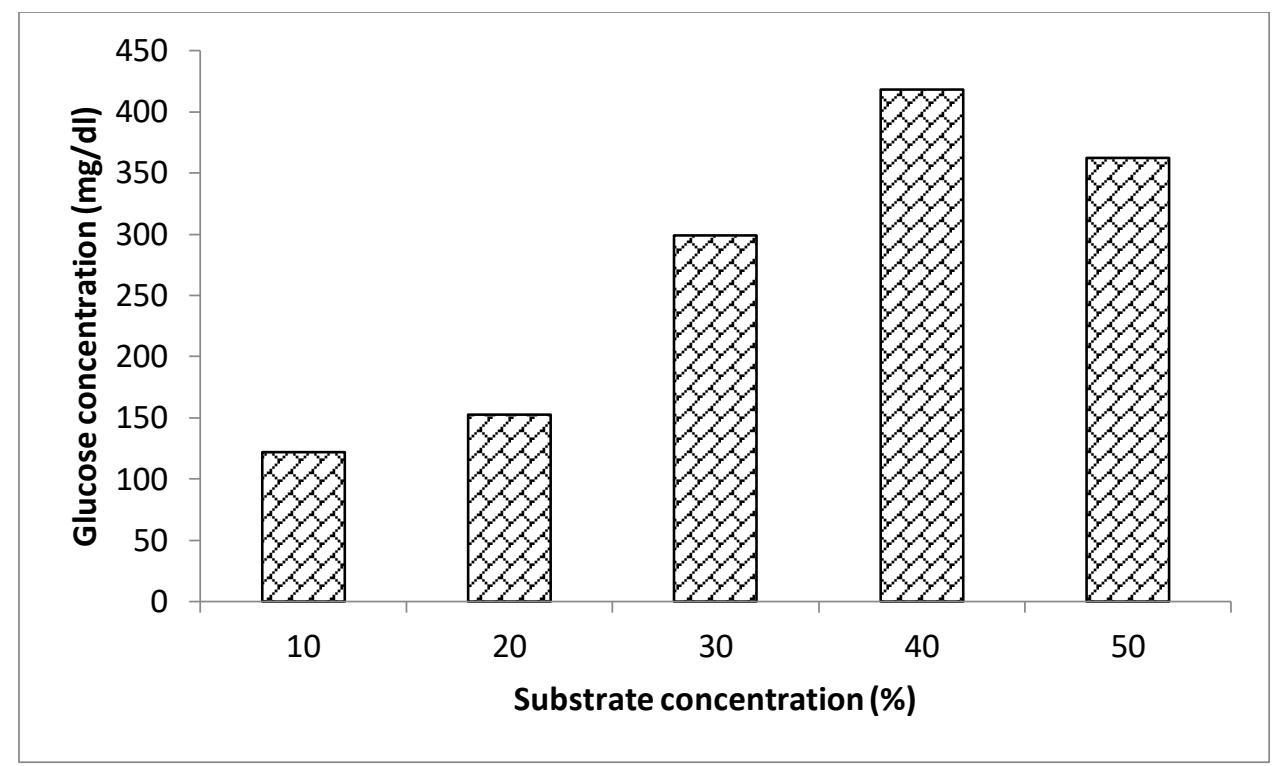

Figure 1: The concentration of released glucose at different substrate concentrations.

\subsubsection{The effect of enzyme concentration}

The enzyme concentration is considered an important factor for the degradation of complex molecules (figure 2). In the current experiment, the obtained data showed how much the enzyme concentration is critical for its activity. As shown in figure 3, the enzyme activity is gradually increased by increasing its concentration. The highest glucose concentration was recorded as $482.5 \mathrm{mg} / \mathrm{dl}$ at $100 \mu 1$ of $\alpha$-amylase enzyme; however, the concentration of glucose was recorded as $130.4 \mathrm{mg} / \mathrm{dl}$ after using $20 \mu \mathrm{l}$ of the enzyme using the same incubation conditions. The same observation was shown at 60 and $80 \mu 1$ of the enzyme that showed glucose concentrations of 248.4 and $260.9 \mathrm{mg} / \mathrm{dl}$ respectively. These observations are strongly matched with (Nagodawithana \& Steinkraus, 1976; Noufal et al., 2017) who reported that the increase of enzyme concentration is proportional to its activity.

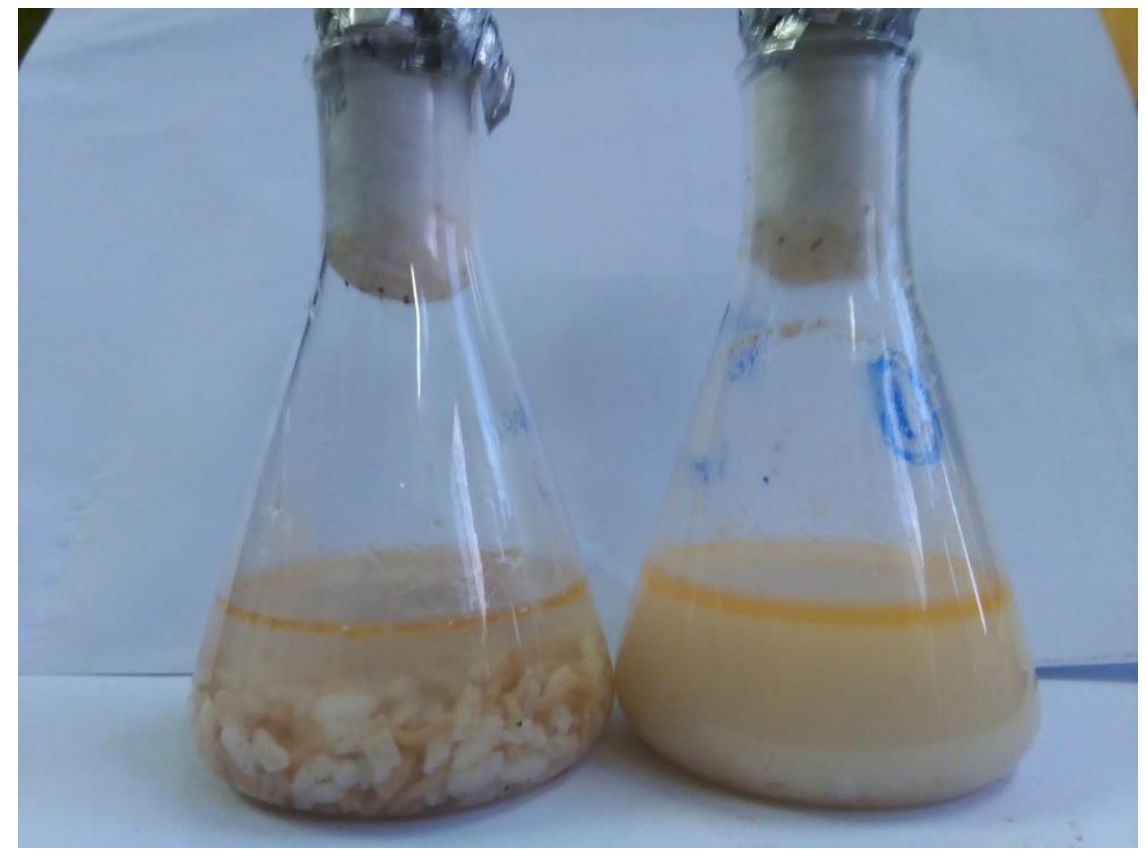

Figure 2: Biodegradation of cooked rice grains by an $\alpha$-amylase enzyme. The left flask is untreated rice grains and the right flask is the treated rice grains. 


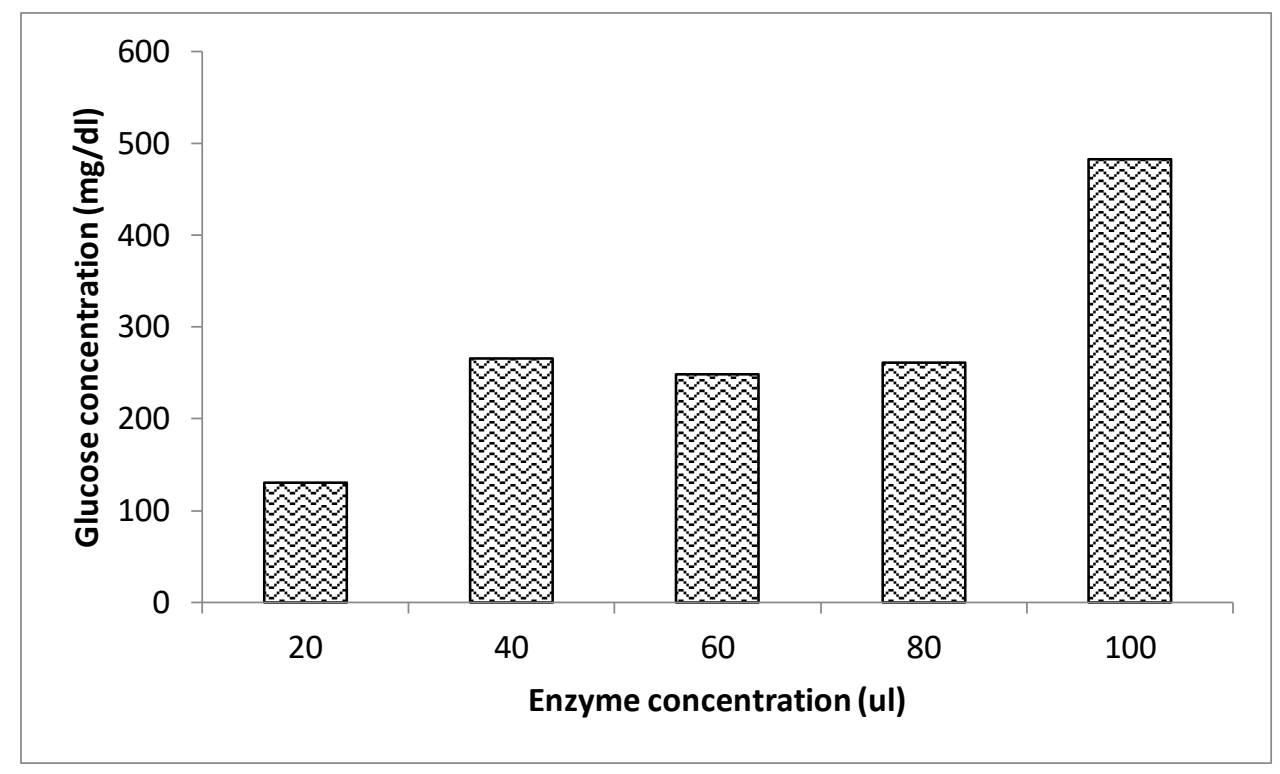

Figure 3: The concentration of released glucose at different $\alpha$-amylase concentrations.

\subsection{Effect of immobilization on bioethanol production}

The ability of Saccharomyces cerevisiae strain to produce bioethanol at free and immobilized status was recorded. The yeast strain preferred to produce bioethanol when being free rather than being immobilized. The concentration of produced ethanol was $423.5 \mathrm{mg} / \mathrm{dl}$ when free cells were used for the fermentation process; whenever a lower concentration of ethanol $(319.2 \mathrm{mg} / \mathrm{dl})$ was produced by the immobilized cells.

\subsection{Polymeric separation of ethanol/water mixture}

\subsubsection{Membrane characterization}

The morphological appearance of both CS and SA membranes were characterized by SEM (figure 4). The surface of both membranes appears to have a smooth and homogeneous surface and haven't any cracks (Abu-Saied et al., 2017; Rosi, Iskandar,
Abdullah, \& Khairurrijal, 2014). Ion-exchange capacity refers to the density of ionizable hydrophilic groups in the membrane matrix, which are responsible for the IC of the membranes, and this is an indirect approximation of the proton conductivity (Abu-Saied et al., 2013; Abu-Saied et al., 2012; Becker \& Schmidt-Naake, 2002; M. Eldin et al., 2011; M. M. Eldin et al., 2011). IEC results of CS and SA membranes were reported to be 1.54 and 1.04 (meq/g), respectively. This result illustrates that both membranes have acceptable IEC and suitable for use in the separation application technique. The contact angle was employed to characterize the relative hydrophilicity or hydrophobicity of each membrane surface. CS membrane resulted in contact angle theta (R) 47.80 and theta (L) 46.87, and SA membrane showed theta (R) 48.65 and theta (L) 47.23. These results were obtained in the hydrophilic characteristics range, and hence CS and SA are considered hydrophilic materials (Kalyani, Smitha, Sridhar, \& Krishnaiah, 2008; Sunitha, Satyanarayana, \& Sridhar, 2012). 

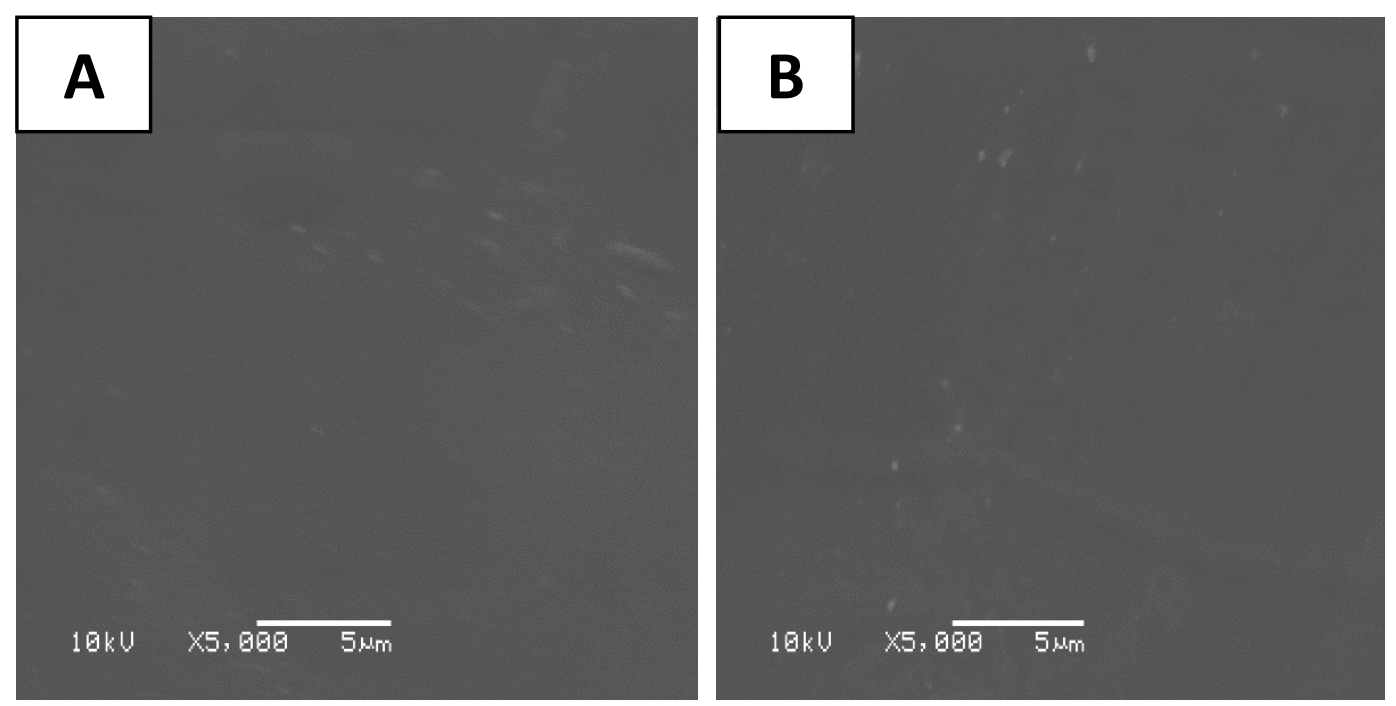

Figure 4: SEM of (a) chitosan membrane and (b) sodium alginate membrane.

\subsubsection{Application of the polymeric membrane in the separation of ethanol/water mixture.}

The separation of ethanol from water that was previously reported in many research articles included many separation techniques. In the last few years, the pervaporation technique became the favorable technique for the separation technology (Gongping, Wang, Wanqin, \& Nanping, 2012; Sun, Lu, Chen, \& Jiang, 2008). The current work did not depend on the same mechanism of pervaporation. It depends on using CS and SA polymeric membranes in separating ethanol/water mixture and purifying the produced bioethanol from other broth components after the fermentation process. The separation was depending on using amicon cells with different nitrogen pressures as an alternative system instead of a pervaporation system.

The separation process was performed for two different ethanol/water resources. The first resource was prepared in the laboratory with a concentration of $25 \%$ chemically prepared ethanol in water. While the second was depending on the separation of $30 \%$ produced bioethanol from the other broth components.

\section{- Separation of $25 \%$ chemically prepared ethanol/water mixture}

Different nitrogen pressures from 20 to 60 psi were applied for $12 \mathrm{hr}$ as shown in table 1 . The results showed that the highest permeate volume and concentration was obtained at 30 psi. As shown in figure 5 ( $\mathrm{A}$ and $\mathrm{B}$ ) both permeate volume and permeate concentration were dramatically increased with pressure values from 20 to 30 psi. The permeate volume was increased from 1500 to $3000 \mu \mathrm{l}$; while, the permeate concentration was increased from 10.34 to $50.29 \mathrm{mg} / \mathrm{ml}$ using CS membrane. Also, the permeate volume was increased from 1200 to 3300 $\mu \mathrm{l}$; while, the permeate concentration was increased from 15.22 to $45.66 \mathrm{mg} / \mathrm{ml}$ using SA membrane.

As shown in figure 6 (A and B) the highest flux of permeate and separation factor under $30 \mathrm{psi}$ nitrogen pressure value were reported as $49.15\left(\mathrm{mg} / \mathrm{m}^{2} . \mathrm{h}\right)$ and 80.51 for CS membrane, but it was recorded as 44.16 $\left(\mathrm{mg} / \mathrm{m}^{2} . \mathrm{h}\right)$ and 86.56 for SA membrane, respectively. However, increasing nitrogen pressure from 40 to 60 psi resulted in a dramatic decrease in permeate flux and an increase in the separation factor. It worth mentioning that the flux of permeate and separation factor was calculated by equations reported by (Zou et al., 2012). 
Table 1: Separation process of $25 \%$ chemically prepared ethanol from water using CS and SA membranes.

\begin{tabular}{|c|c|c|c|c|c|c|}
\hline $\begin{array}{c}\text { Membrane } \\
\text { Type }\end{array}$ & $\begin{array}{c}\text { Time } \\
(\mathbf{h})\end{array}$ & $\begin{array}{c}\text { Nitrogen } \\
\text { pressure } \\
(\mathbf{p s i})\end{array}$ & $\begin{array}{c}\text { Permeate } \\
\text { volume } \\
(\boldsymbol{\mu l})\end{array}$ & $\begin{array}{c}\text { Permeate } \\
\text { concentration } \\
\text { of ethanol } \\
(\mathbf{m g} / \mathbf{m l})\end{array}$ & $\begin{array}{c}\text { Flux of } \\
\text { permeate } \\
\left(\mathbf{m g} / \mathbf{m}^{2} \cdot \mathbf{h}\right)\end{array}$ & $\begin{array}{c}\text { Separation } \\
\text { factor }\end{array}$ \\
\hline \multirow{4}{*}{ CS } & 3 & 20 & 1500 & 10.34 & 25.96 & 30.62 \\
\cline { 2 - 7 } & 4 & 30 & 3000 & 50.29 & 49.15 & 80.51 \\
\cline { 2 - 7 } & 2 & 40 & 1000 & 34.36 & 30.4 & 39.03 \\
\cline { 2 - 7 } & 2 & 50 & 600 & 17.11 & 27.13 & 40.9 \\
\hline \multirow{4}{*}{ SA } & 3 & 60 & 400 & 15.93 & 18.91 & 60.52 \\
\cline { 2 - 7 } & 2 & 20 & 1200 & 15.22 & 20.23 & 32.98 \\
\cline { 2 - 7 } & 3 & 30 & 3300 & 45.66 & 44.16 & 86.56 \\
\cline { 2 - 7 } & 1 & 40 & 1300 & 30.79 & 23.42 & 37.51 \\
\cline { 2 - 7 } & 3 & 60 & 700 & 33.82 & 30.45 & 43.87 \\
\hline
\end{tabular}
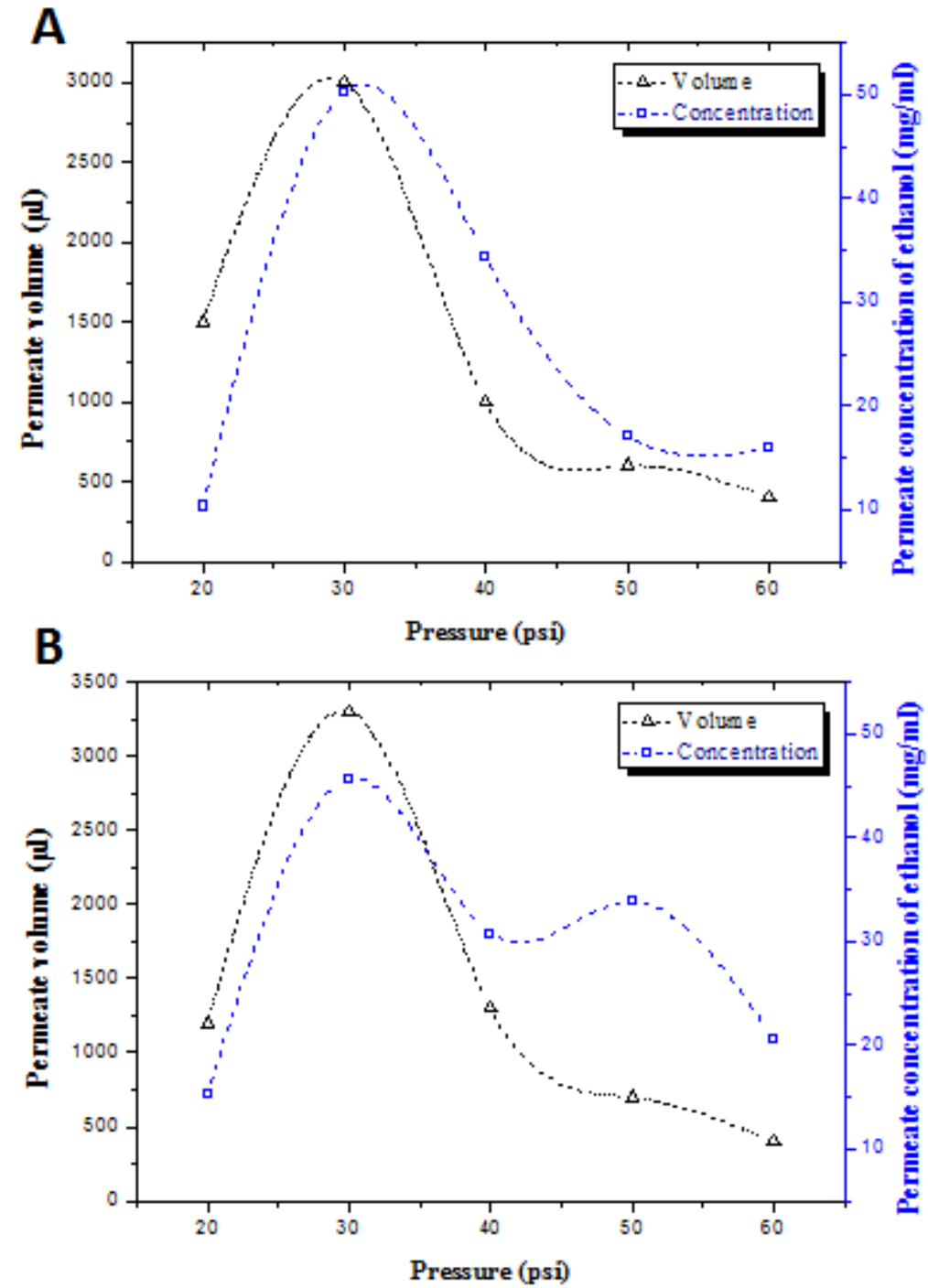

Figure 5: The obtained permeate volume and concentration produced using CS membrane (A) and SA membrane (B) for separation of $25 \%$ ethanol/water mixture. 

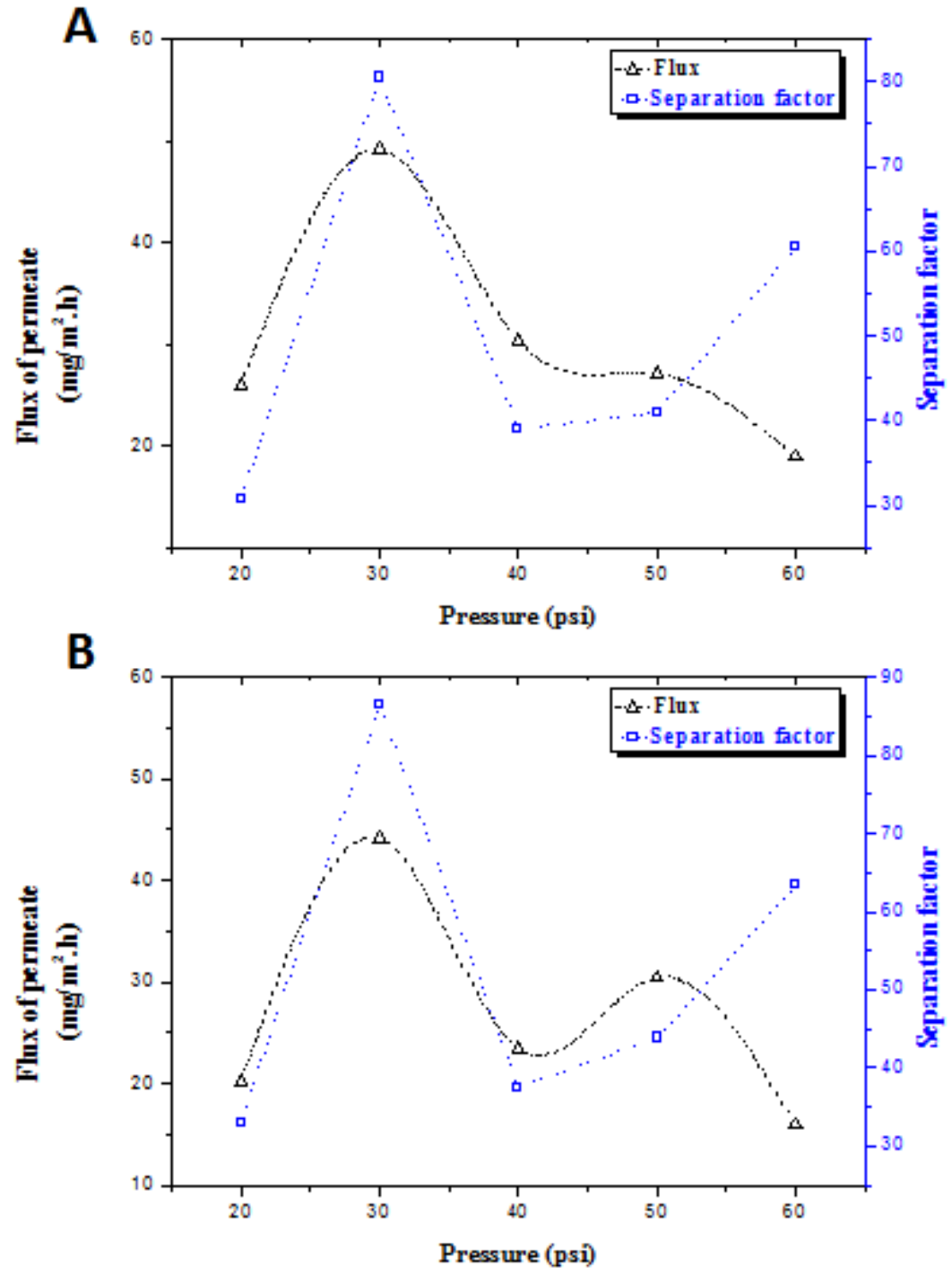

Figure 6: The obtained flux of permeate and separation factor produced using CS membrane (A) and SA membrane (B) for separation of $25 \%$ ethanol/water mixture.

- Separation of $30 \%$ bioethanol/culture broth mixture

The second ethanol resource was obtained biologically as a bio-product of the yeast fermentation process of starchy waste. Table 2 demonstrates that the highest permeate volume was recorded at nitrogen pressure $30 \mathrm{psi}$. As recorded in figure 7 (A and $\mathrm{B}$ ) the permeate volume was increased from 1100 to $2800 \mu \mathrm{l}$ for CS membrane and from 1150 to $2750 \mu \mathrm{l}$ for SA membranes, respectively. However, at nitrogen pressures from 40 to $60 \mathrm{psi}$, the permeate volume was gradually decreased from 1900 to $800 \mu \mathrm{l}$ for CS membrane and from 1800 to $800 \mu \mathrm{l}$ for SA membrane, respectively. Using CS membrane, the highest permeate concentration was recorded as $53.23 \mathrm{mg} / \mathrm{ml}$, which was almost close to the same concentration obtained using SA membrane $(55.10 \mathrm{mg} / \mathrm{ml})$ under the same pressure $(50 \mathrm{psi})$. On the other hand, 50 psi was recorded as the optimum pressure for obtaining the highest permeate flux using both membranes. However, 30 psi was the optimum one for obtaining the highest separation factor using both membranes. As depicted in figure 8A, the highest permeate flux and separation factors were $40.35\left(\mathrm{mg} / \mathrm{m}^{2} . \mathrm{h}\right)$ and 65.21 using CS membrane, respectively. While, the highest permeate flux and separation factors were $44.31\left(\mathrm{mg} / \mathrm{m}^{2} . \mathrm{h}\right)$ and 65.10 using SA membrane, respectively (figure $8 \mathrm{~B}$ ). These results confirm the prolonged stable activity of the prepared polymeric membranes even in the presence of salts and sugars which are present as residues in the fermentation liquor (Chovau, Gaykawad, Straathof, \& Van der Bruggen, 2011). 
Table 2: Separation process of 30\% bioethanol from culture broth using CS and SA membranes.

\begin{tabular}{|c|c|c|c|c|c|c|}
\hline $\begin{array}{c}\text { Membrane } \\
\text { Type }\end{array}$ & $\begin{array}{c}\text { Time } \\
(\mathbf{h})\end{array}$ & $\begin{array}{c}\text { Nitrogen } \\
\text { pressure } \\
(\mathbf{p s i})\end{array}$ & $\begin{array}{c}\text { Permeate } \\
\text { volume } \\
(\boldsymbol{\mu l})\end{array}$ & $\begin{array}{c}\text { Permeate } \\
\text { concentration } \\
\text { of ethanol } \\
(\mathbf{m g} / \mathbf{m l})\end{array}$ & $\begin{array}{c}\text { Flux of } \\
\text { permeate } \\
\left(\mathbf{m g} / \mathbf{m}^{\mathbf{2}} \mathbf{. h}\right)\end{array}$ & $\begin{array}{c}\text { Separation } \\
\text { factor }\end{array}$ \\
\hline \multirow{4}{*}{ CS } & 2 & 20 & 1100 & 19.53 & 21.18 & 29.28 \\
\cline { 2 - 7 } & 4 & 30 & 2800 & 35.48 & 37.44 & 65.21 \\
\cline { 2 - 7 } & 3 & 40 & 1900 & 46.78 & 33.24 & 53.48 \\
\cline { 2 - 7 } & 2 & 50 & 900 & 53.23 & 40.35 & 45.59 \\
\hline \multirow{4}{*}{ SA } & 1 & 60 & 800 & 44.21 & 31.20 & 38.69 \\
\cline { 2 - 7 } & 2 & 20 & 1150 & 19.12 & 21.76 & 28.97 \\
\cline { 2 - 7 } & 2 & 30 & 2750 & 37.94 & 36.27 & 65.10 \\
\cline { 2 - 7 } & 2 & 40 & 1800 & 48.36 & 32.84 & 52.99 \\
\cline { 2 - 7 } & 3 & 50 & 1000 & 55.10 & 44.31 & 52.55 \\
\hline
\end{tabular}

A

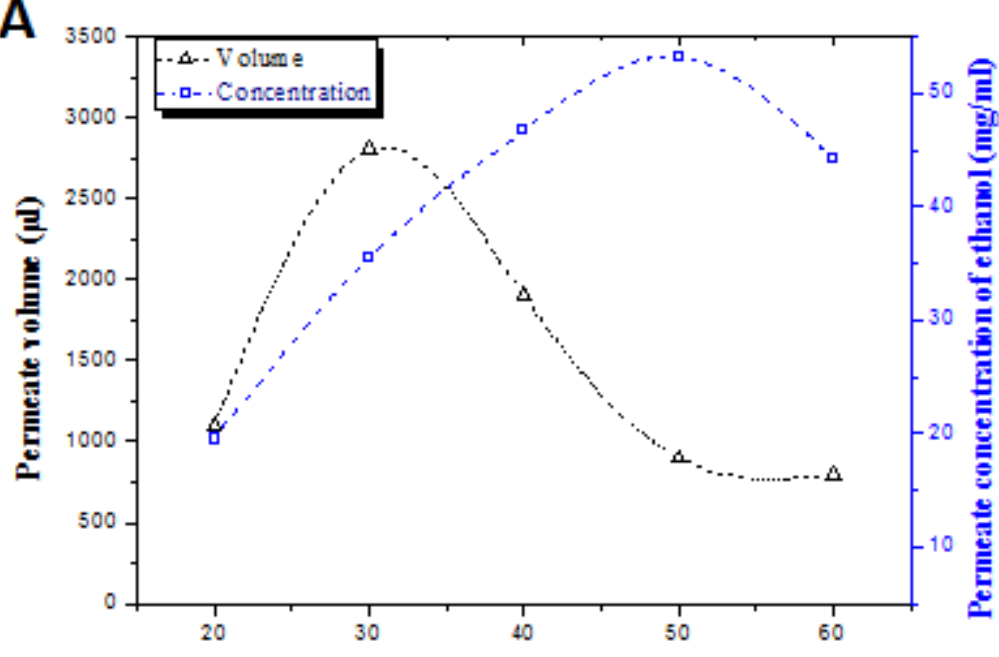

B

Pressure (psi)

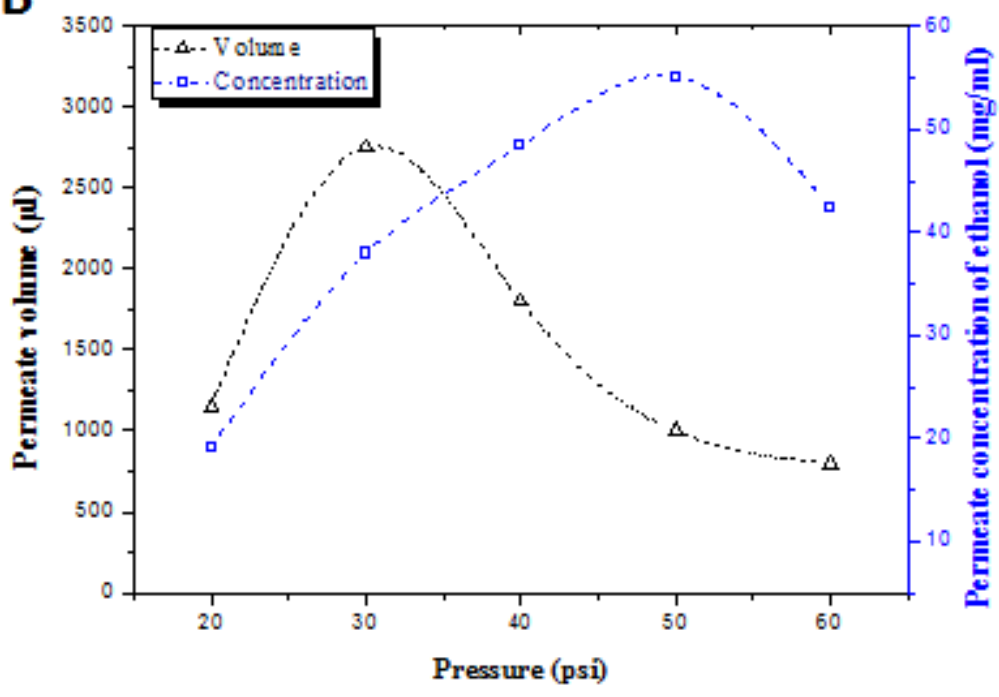

Figure 7: The obtained permeate volume and concentration produced using CS membrane (A) and SA membrane (B) for separation of $30 \%$ bioethanol/culture broth mixture. 

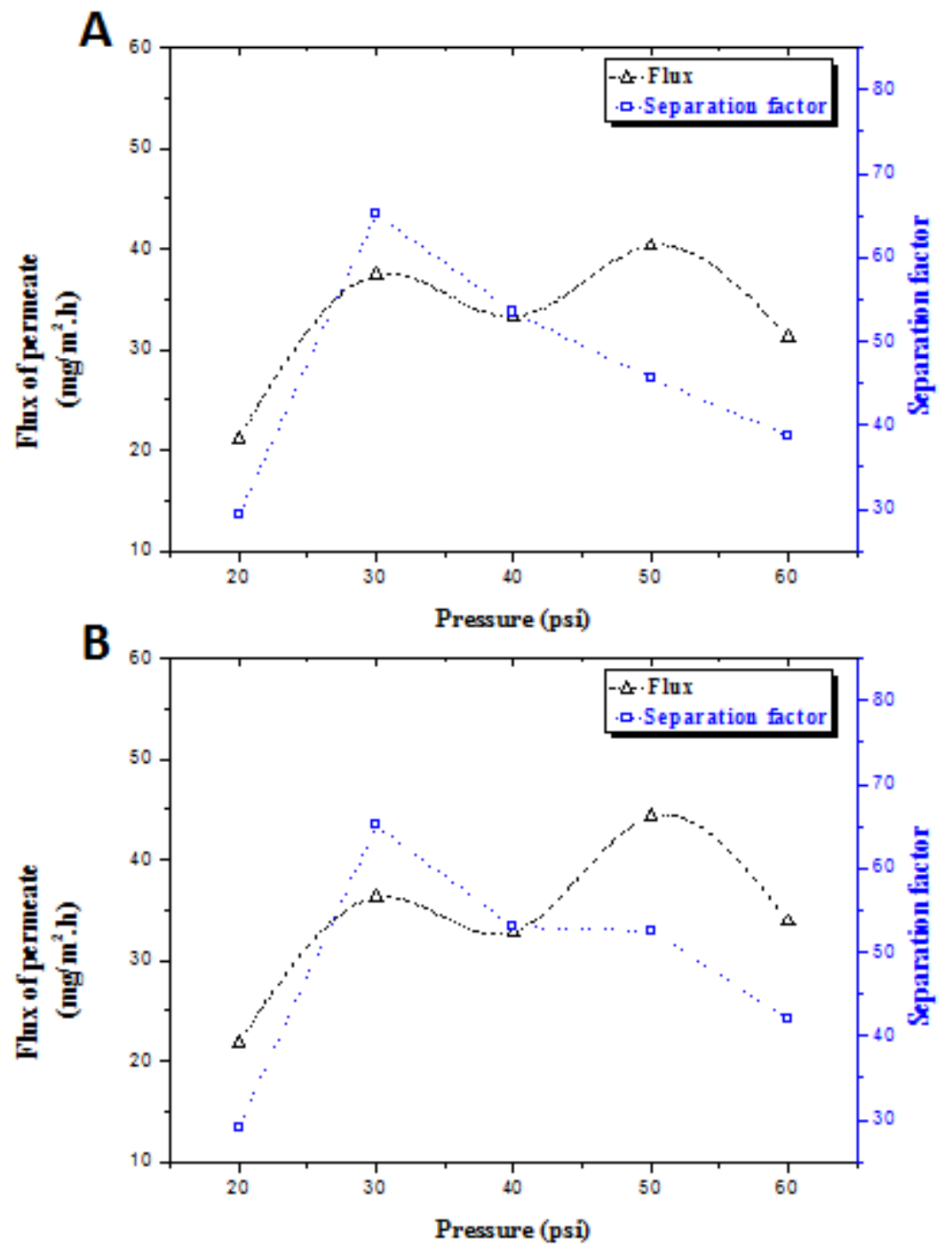

Figure 8: The obtained flux of permeate and separation factor produced using CS membrane (A) and SA membrane (B) for separation of $30 \%$ bioethanol/culture broth mixture.

\section{4- Conclusion}

The present work deals with the bioconversion of environmental waste (starch) into bio-ethanol. The highest glucose units were liberated using $\alpha$-amylase enzyme during enzymatic hydrolysis. The highest bioethanol production of $423.5 \mathrm{mg} / \mathrm{dl}$ was obtained after anaerobic fermentation of the free yeast cells at $30^{\circ} \mathrm{C}$ without shaking. CS and SA membranes were prepared and used in the separation of bioethanol/culture broth process by using amicon cell at different nitrogen pressures with 30 psi as the best optimum one. CS and SA membranes were characterized by SEM, IEC and the hydrophilicity/hydrophobicity of the prepared membranes was also investigated using contact angle. The obtained results confirmed that the prepared polymeric membranes can be used for the separation of different types of ethanol/water mixtures through the pervaporation system or any other systems including our system.

\section{REFERENCES}

Abu-Saied, M., Fontananova, E., Drioli, E., \& Eldin, M. M. (2013). Sulphonated poly (glycidyl methacrylate) grafted cellophane membranes: Novel application in polyelectrolyte membrane fuel cell (PEMFC). Journal of Polymer Research, 20(7), 187.

Abu-Saied, M., Wycisk, R., Abbassy, M. M., El-Naim, G. A., El-Demerdash, F., Youssef, M., . . . Pintauro, P. N. (2017). Sulfated chitosan/PVA absorbent membrane for removal of copper and nickel ions from aqueous solutions-Fabrication and sorption studies. Carbohydrate Polymers, 165, 149-158.

Abu-Saied, M., Elzatahry, A., El-Khatib, K., Hassan, E., El-Sabbah, M., Drioli, E., \& Eldin, M. (2012). Preparation and characterization of novel 
grafted cellophane-phosphoric acid-doped membranes for proton exchange membrane fuel-cell applications. Journal of applied polymer science, 123(6), 3710-3724.

Alvira, P., Tomás-Pejó, E., Ballesteros, M., \& Negro, M. (2010). Pretreatment technologies for an efficient bioethanol production process based on enzymatic hydrolysis: a review. Bioresource Technology, 101(13), 48514861.

Balasubramanian, K., Ambikapathy, V., \& Panneerselvam, A. (2011). Studies on ethanol production from spoiled fruits by batch fermentations. Journal of Microbiology and Biotechnology Research, 1(4), 158-163.

Becker, W., \& Schmidt-Naake, G. (2002). Proton Exchange Membranes by Irradiation Induced Grafting of Styrene Onto FEP and ETFE: Influences of the Crosslinker N, NMethylene-bis-acrylamide. Chemical engineering \& technology, 25(4), 373-377.

Bello, R. H., Linzmeyer, P., Franco, C. M. B., Souza, O., Sellin, N., Medeiros, S. H. W., \& Marangoni, C. (2014). Pervaporation of ethanol produced from banana waste. Waste Management, 34(8), 1501-1509.

Braide, W., Kanu, I., Oranusi, U., \& Adeleye, S. (2016). Production of bioethanol from agricultural waste. Journal of Fundamental and Applied Sciences, 8(2), 372-386.

Chovau, S., Gaykawad, S., Straathof, A. J., \& Van der Bruggen, B. (2011). Influence of fermentation by-products on the purification of ethanol from water using pervaporation. Bioresource Technology, 102(2), 1669-1674.

Eldin, M., Elzatahry, A., El-Khatib, K., Hassan, E., ElSabbah, M., \& Abu-Saied, M. (2011). Novel grafted Nafion membranes for protonexchange membrane fuel cell applications. Journal of applied polymer science, 119(1), 120-133.

Eldin, M. M., Abu-Saied, M., Elzatahry, A., El-Khatib, K., Hassan, E., \& El-Sabbah, M. (2011). Novel Acid-Base Polyvinyl chloride-Doped OrthoPhosphoric Acid Membranes for Fuel Cell Applications. Int. J. Electrochem. Sci, 6, 54175429.

Gongping, L., Wang, W., Wanqin, J., \& Nanping, X. (2012). Polymer/ceramic composite membranes and their application in pervaporation process. Chinese Journal of Chemical Engineering, 20(1), 62-70.
Goshadrou, A., Karimi, K., \& Taherzadeh, M. J. (2013). Ethanol and biogas production from birch by NMMO pretreatment. Biomass and bioenergy, 49, 95-101.

Hashem, M., Asseri, T. Y., Alamri, S., \& Alrumman, S. (2018). Feasibility and Sustainability of Bioethanol Production from Starchy restaurants' Bio-wastes by New Yeast Strains. Waste and Biomass Valorization, 110.

Kalyani, S., Smitha, B., Sridhar, S., \& Krishnaiah, A. (2008). Pervaporation separation of ethanol-water mixtures through sodium alginate membranes. Desalination, 229(1-3), 68-81.

Kim, J. H., Lee, J. C., \& Pak, D. (2011). Feasibility of producing ethanol from food waste. Waste Management, 31(9-10), 2121-2125.

Korelskiy, D., Leppäjärvi, T., Zhou, H., Grahn, M., Tanskanen, J., \& Hedlund, J. (2013). High flux MFI membranes for pervaporation. Journal of membrane science, 427, 381-389.

Mahalakshmi, M., Angayarkanni, J., Rajendran, R., \& Rajesh, R. (2011). Bioconversion of cotton waste from textile mills to bioethanol by microbial saccharification and fermentation. Annals of biological research, 2(3), 380-388.

Matsakas, L., \& Christakopoulos, P. (2015). Ethanol production from enzymatically treated dried food waste using enzymes produced on-site. Sustainability, 7(2), 1446-1458.

Nagodawithana, T. W., \& Steinkraus, K. H. (1976). Influence of the rate of ethanol production and accumulation on the viability of Saccharomyces cerevisiae in" rapid fermentation". Applied and Environmental Microbiology, 31(2), 158-162.

Noufal, M. J., Li, B., \& Maalla, Z. A. (2017). Production of bioethanol from waste potatoes. IOP Conference Series: Earth and Environmental Science (Vol. 59, p. 012006): IOP Publishing.

Onuki, S., Koziel, J. A., van Leeuwen, J. H., Jenks, W. S., Grewell, D., \& Cai, L. (2008). Ethanol production, purification, and analysis techniques: a review. 2008 Providence, Rhode Island, June 29-July 2, 2008 (p. 1): American Society of Agricultural and Biological Engineers.

Rosi, M., Iskandar, F., Abdullah, M., \& Khairurrijal. (2014). Hydrogel-polymer electrolytes based on polyvinyl alcohol and hydroxyethylcellulose for supercapacitor applications. International Journal of Electrochemical Science, 9(8), 4251-4256. 
Saha, P., Baishnab, A., Alam, F., Khan, M., \& Islam, A. (2014). Production of bio-fuel (bio-ethanol) from biomass (Pteris) by fermentation process with yeast. Procedia Engineering, 90, 504-509.

Sarkar, N., Ghosh, S. K., Bannerjee, S., \& Aikat, K. (2012). Bioethanol production from agricultural wastes: an overview. Renewable energy, 37(1), 19-27.

Srivastava, A. K., Agrawal, P., \& Rahiman, A. (2014). Pretreatment and production of bioethanol from different Lignocellulosic biomass. International Journal, 2(4), 888-896.

Sun, H., Lu, L., Chen, X., \& Jiang, Z. (2008). Surfacemodified zeolite-filled chitosan membranes for pervaporation dehydration of ethanol. Applied Surface Science, 254(17), 53675374.

Sunitha, K., Satyanarayana, S., \& Sridhar, S. (2012). Phosphorylated chitosan membranes for the separation of ethanol-water mixtures by pervaporation. Carbohydrate Polymers, 87(2), 1569-1574.

Taha, T. H., Alamri, S. A., Mahdy, H. M., \& Hafez, E. E. (2013). The effects of various immobilization matrices on biosurfactant production using hydrocarbon (HC)degrading marine bacteria via the entrapment technique. Journal of Biological Sciences, 13(2), 48.

Tanimura, A., Kikukawa, M., Yamaguchi, S., Kishino, S., Ogawa, J., \& Shima, J. (2015). Direct ethanol production from starch using a natural isolate, Scheffersomyces shehatae: toward consolidated bioprocessing. Scientific reports, 5, 9593.

Vane, L. M. (2008). Separation technologies for the recovery and dehydration of alcohols from fermentation broths. Biofuels, Bioproducts and Biorefining, 2(6), 553-588.

Zaldivar, J., Nielsen, J., \& Olsson, L. (2001). Fuel ethanol production from lignocellulose: a challenge for metabolic engineering and process integration. Applied microbiology and biotechnology, 56(1-2), 17-34.

Zou, X., Bazin, P., Zhang, F., Zhu, G., Valtchev, V., \& Mintova, S. (2012). Ethanol Recovery from Water Using Silicalite-1 Membrane: An Operando Infrared Spectroscopic Study. ChemPlusChem, 77(6), 437-444. 